\title{
»Reclaiming" the City: A Collective Endeavor
}

\author{
Sergiy Ilchenko
}

\begin{abstract}
This contribution elaborates upon the appropriation of urban space in spatiotemporal and procedural interventions in the example of the city of Kharkiv, as well as the impact of urban space on the process of how various groups rediscover and use various parts of the city. Being moved during collective actions - in the sense of feeling urged to move along - goes beyond routine practices by influencing the city and its perception. It seems that these general processions, celebrations, and festive activities of the residents are their contributions to the process of "urban renaissance - the rebirth of interest in the urban way of life. Since public spaces reflect the historical inheritance of local communities, joint transformative actions such as, "appropriation", "production«, and "governance" of urban spaces are considered. This article advocates for the practice of domestication of urban space by the local community, as well as the need for the existence of "urban lagoons" - free (unregulated) areas of the city used as resources for urban development and interaction of citizens.
\end{abstract}

Keywords: Urban Environment; Public Space; Urban Communing; Collective Action; Space Domestication.

\section{Introduction}

The transformation of urban landscapes can be instigated by the actions of authorities, business activities, or urban communities, where each actor has their own interest and levers of influence. If we focus on the activities of citizens (collective action) and their impact on urban space - we notice that they do not necessarily result in physical improvements (Koch/Latham 2013: 10). To a large degree it is a transformation in the mental attitude toward the ownership of urban space by the wider community, and inclusion of the latter into daily life (sometimes through temporary use, and through the increased activity of the residents).

Releasing the "abstract u urban space (Lefebvre 1996[1968]) from objectification is a step-by-step process of the adaptation of the cityscape by its residents. This domestication (Koch/Latham 2013:10) of abstract space by means 
of communal action: festive processions, urban »occupation«, artistic practice and public expression within the city environment, creates a complex pattern of relationships, claims, and appeals by varying residential groups as to their particular rights to the city (Lefebvre 1996; Harvey 2012). Collective actions by the residents are rather more of a temporal nature; and such interventions in the urban space are limited in time. At the same time, these short-term influences affect the perception (or acceptance) of certain urban spaces, not always leading to physical changes in the latter, but influencing their further development.

This article is based on continuous long-term, active, participant observation of the communal activities of residents and the transformation (over time) of their perception of public spaces of Kharkiv, and the observation of the gradual inclusion of the latter into the daily practice of local society, which took place in the period from 2021 until recently. It is safe to say that not all public spaces and open environments can be classified as civil (Douglass 2007: 49). In order to discuss this aspect of inclusivity of communal space the researcher defines the latter as: open to a wide range of civil use, whether in private or state ownership, with equal rights for everyone to enter it and initiate contact with each other (cf. Goffman 2008). In this way we can define the aspect of inclusivity in urban space as an intangible manifestation of disputes and power struggles between civil society and the state, where civil space is not only a place but also a process similar to a physical or computer network (Douglass 2007: 49). Long-term observation of collective actions and their choice of venues (locations), inadvertently draws our attention to »urban lagoons - abandoned (overlooked during urban planning) fragments of the urban fabric, and to the significance of "urban lagoons « in the life of local communities. This new term is different from the urban voids that emerge between a public and private space. On the one hand, these are plots that are privately owned (not used for various reasons), on the other, these are the territories of public institutions that have limited access, due to specifics of the local area.

\section{Theoretical and Conceptual Framework}

Coming back to the concept of the »domestication « of urban space, it is worth pointing out that it is considered by Koch and Latham (2013: 9) from the stance of providing »domestic « qualities (a sense of trust, comfort, or amenity). At the same time, academic and urban rhetoric in the context of 
encroachment on the democratic mood of public space, translates the term »domestication « in a negative way, reducing the contemporary definition of communal environments to control, pacification, disciplining, and commercialization (Jackson 1998, Allen 2006; Zukin 2009). The criticism directed toward aspects of authority and global cultural structure appears reasonable in the case of the production of spaces by either the government (De Certeau/ Mayol 1998[1980]), or the administration (Lefebvre 1996[1968]). Nevertheless, a lithe (from a certain perspective) system of "government/bureaucratic civil society", where one predominantly produces spaces while others consume (or interpret) them does not, in the full sense, carry the colorful assortment of specific disputes and shifts in the power balance in relation to communal spaces. The researcher proposes a model of development where the strategies of polarized social groups become a resource for further urban development and human interaction. Here, communal endeavors take center stage, and the right to the city is understood as an inclusive freedom of the broader urban community that is integrated into its daily existence (Harvey 2012).

Sharing the concern that cities are gradually losing the democratic nature of public space and the authentic forms of public life that have historically defined them, Koch and Latham (2013: 9) consider the latter to be exaggerated, believing that the term domestication can, and should be, understood differently - as a process of adjustment and adaptation to others as part of routine practice (ibid.: 17). Communal actions in particular develop into unanimous practices and become a »laboratory« in which to develop a different (reinvented) public sphere (Vaiou/Kalandides 2016: 461).

The cooperation of city inhabitants is realized through everyday spatial practices of urban communing and collective endeavors (Bresnihan/Byrne 2015:36) including forms of appropriation, ownership, and governance. It should be noted that the majority of these collective actions are a targeted response to the challenges and limitations of various dimensions of social and cultural life (ibid.: 40).

The processes of urban development (in each specific case) cannot be reduced to only the influence of government or business. We should take into account that inclusive public spaces with a high degree of independence from state and corporate economies exist as well. Both the state-led and independent processes link to the complexity of urban development processes. They are created through implicit and explicit negotiation, as well as the broadening sphere of social privilege and opportunity (Douglass 2007: 19). 
They are crucial to the exchange of ideas, cooperation, and the involvement of corporate and governmental actors in the active development of cities (ibid.: 19). Under these circumstances, we can consider the perspective that:

»views domestication as a process through which big political and social projects - largely the ideas of politicians, experts and social institutions become enmeshed within everyday practices and processes of social reproduction«(Koch/Latham 2013: 13-14).

In this study, the influence of joint (collective) endeavors upon both, the material (and immaterial) components of civil spaces and the development of urban culture, is of central interest. It should be noted that the analysis of public spaces is not limited to parks, squares, plazas and public transportation hubs. Urban streets (and courtyards) are also considered, regardless of their function as conduits of movement, but as social and public spaces as well (von Schönfeld/Bertolini 2017: 49). Initial data for the study were obtained by participant observation, the secondary data were obtained by chronological reconstruction of archival materials and unstructured interviews with the organizers of the campaigns with further interpretation of the obtained materials. The main issue of this study is the impact of collective action on the formation of attachment to a place. This issue led to the question of the impact of collective processions (movements) on the expansion of the public space of the city. The influence of such collective actions on the emergence of inclusive public spaces with a high degree of independence from the state and corporate economy was investigated.

\section{Results}

\section{Context}

Kharkiv is the second largest city in Ukraine in terms of population (over 1.43 million), a large industrial, scientific and educational center located near the border with Russia. It's a multicultural city (with large Vietnamese and Afghan communities), the diversity of which is complemented by about 20,000 foreign students studying at the city universities. The city is gradually joining the European integration processes. The processes of civil society formation (accelerated after the »Revolution of Dignity«) are a characteristic of countries with transition economies. The civil society reaction to 
Russian aggression in 2014 intensified the consolidation process of various groups. The collective influence of European integration processes and the growth of civil consciousness accelerated the pace of various public organizations formation. Also, the attention of local residents to the processes of urban development is increasing and, as a result, a sense of responsibility for the city is on the rise too. In the process of including citizens in urban planning, Kharkiv is distinguished by a much more variegated configuration of various groups, movements, and associations all claiming their rights to public space.

\section{Resumption of Collective Action Practices}

Since public space is a reflection of the cultural heritage of local residents, let us take a quick trip to the year 2012 to seemingly insignificant (at first sight) events. It seems that these events heavily influenced the perception of collective practices by the local residents. Three processions of Dutch fans (who came to Kharkiv to support their national team playing at the local stadium), which took place before the matches on June 9, 13 and 17, 2012, demonstrated to local residents an unusual practice of temporal appropriation of street space. It was a different practice from the routine method of moving around the city. Similar processions had been organized by the communist authorities until the period of independence, but the participation of the townspeople was rather compulsory. The format of a selforganized march (not tied to political protests) was not typical for Kharkiv. The function of public space is revealed by its critical function - which: »allows people to linger, interact with one another, ignore each other, read, sit, stand or even lie down« (von Schönfeld/Bertolini 2017: 49). Furthermore, the final parade included a large number of local residents. In the first procession, - the overwhelming majority were Dutch, Danish, and German fans, accompanied by traffic police, while local residents were more likely to be spectators. A grand show was presented with orange uniforms, a double decker bus, the "Orange Club«, Dutch patriotic hymns were sung by the attendants, and ribbon streamers were shot into the air overhead (Tarasova 2012a). The city welcomed over 10,000 Dutch football fans, for the accommodation of which the "Orange Camp « was erected on the grounds of the Zhuravlivs'kiy River Park, housing several thousand people (Tarasova 2012b). The closing parade was different. It was composed of a large number of local residents, much fewer traffic police, and with about 50 local cyclists at the 
head of the procession. What changed in those eight days? It seems it was the perception of urban environment and the understanding of one's own right to claim the space for one's own means, which is mentioned by David Harvey (2012). These processions were choreographed by Dutch activists and were lined up around the »orange bus " opening the procession, and there were musicians (among the fans) in different parts of the column:

»Kharkiv residents reacted to Dutch 'fans'< requests to support their team and wore the colors of the Dutch national team, and participated in the march alongside them. Many locals also cheered the Dutch fans along the streets, waving from windows and balconies, holding Dutch flags and posters, wishing the Netherlands victory and shouting >Hollandk. In turn, the Dutch carried banners with the words >Thank you, Kharkiv!, while also repeatedly chanting $>$ Ukraine « (Tarasova 2012c).

This small event seems to have somewhat changed the local community's perception of urban space. Manifestations of collective action in the city center should be considered in two respects. The first concerns the resulting sum activity of cultural and educational institutions, local communities, and city administration. The significance and influence of local institutions on the urban activity of the residents should be considered in the context of compelling changes (the participation of the city in global projects). Thus, in 2010, the city was connected with the world wide event "The Night of Museums «. ${ }^{1}$ Kharkiv's Museum of Literature was the first of the four city museums to join the event. The key aim of this format is to bring forth an interconnection between the museum and urban space, in order to bring the internal world of the museums out onto the streets and to the inhabitants of the city, creating new points of contact and encouraging easy access to art exhibitions and cultural events. In 2012, 14 museums and galleries joined »The Night of Museums«, with the majority of events taking place in the open, unconfined by museum walls. ${ }^{2}$

1 »Ukrainian museums are joinining an international action >Museums night «, in: NOVOSTI N, May 14, 2010, 15:45, https://novosti-n.org/ukraine/Ukraynskye-muzey-prysoedynyatsyak-mezhdunarodnoj-akczyy-Noch-muzeev--21581, accessed July 15, 2021.

2 "14 Kharkiv Museums and Galleries welcome to the >Museums night«, in: Official Site of Kharkov City Council, Mayor, Executive Committee, May 9, 2012, 11:52, https://www.city. kharkov.ua/ru/news/14-muzeyiv-i-galerey-harkova-zaproshuyut-na-nich-muzeyiv-13556. htm, accessed July 15, 2021. 
The museum courtyards and surroundings became sites for exhibitions, installations, concerts, literary evenings, theatre performances, fire shows, and even telescopic observations of the Moon and Saturn. Over time, more and more organizations embraced this open format event, and in 2013, a total of 18 organizations joined, and the city administration decided to extend the operational hours of public transport. ${ }^{3}$ Similarly, collective festivals (which take place annually) are important to the evolution of new practices of adapting space. Over time, the activities of the Kharkiv Literary Museum expanded beyond the initial event and the space around the museum is now purposefully utilized almost every week. A street library ${ }^{4}$ appears on Bagaliya Street, near the Museum, and the inner courtyard of the museum becomes a platform for numerous exhibitions, ${ }^{5}$ film screenings, ${ }^{6}$ and concerts. ${ }^{7}$ Soon Kharkiv Academy of Design and Arts also joined "The Night of Museums" festival, and later, "Street Day Fest ${ }^{8}{ }^{8}$ which lets artists, musicians, and actors showcase their work in outside spaces. ${ }^{9} \mathrm{~A}$ temporary food court is set up on the campus of the Academy and space is provided for a vintage car show.

3 »18 Kharkiv Museums and Galleries welcome to the >Museums night«, in: Official Site of Kharkov City Council, Mayor, Executive Committee, May 13, 2013, 14:54, https:// www.city.kharkov.ua/ru/news/18-muzeyiv-ta-galerey-harkova-zaproshuyut-na-nichmuzeyiv-19245.html, accessed July 15, 2021.

4 »/Knyzhkova cljumba< starts with the bookcrossing with wrighteress Julia Iljuha«, in: Facebook group >Kharkov - kuda b shodit<, April 11, 2018, https://www.facebook.com/kharkovgo/posts/1018688328280178, accessed July 15, 2021.

5 »Portrait Exhibition of Ukrainian writers >Polychka at the Literary Museum Garden«, in: Litme.com.ua, http://litme.com.ua/vystavka-portretiv-ukrayinskyh-pysmennykiv-polychka-u-sadku-litmuzeyu, accessed July 15, 2021.

6 »Openair Cinema at the Literary Museum«, in: Facebook group «Kharkov - kuda b shodit«, August 14, 2017, https://www.facebook.com/kharkovgo/posts/893992134083132?comment_tracking=\%7B\%22tn\%22\%3A\%22O\%22\%7D, accessed July 15, 2021.

7 »Literary Museum Will Hold a Book Swapping and Ukulele Concert«, in: Newsroom, August 2, 2017, 11:23, https://www.newsroom.kh.ua/ua/node/17575, accessed July 15, 2021.

8 " One Street Day< Festival will be held in Kharkiv on September 19«, in: Stroy Obzor, September 17, 2015, https://stroyobzor.ua/ru/kharkov/news-city/19-sentyabrya-v-kharkove-proydet-festival-den-odnoy-ulicy, accessed July 15, 2021.

9 »One Street Day in Kharkiv - Iskusstv Street«, in: DOZOR.UA, April 18, 2016, 09:40, https:// dozor.com.ua/news/tabloid/1205571.html, accessed July 15, 2021. 


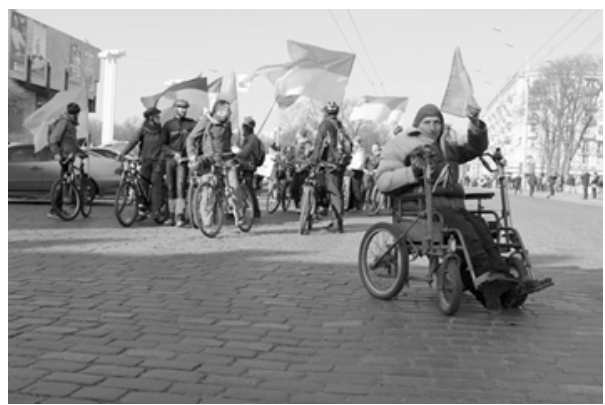

1.

The pro-Ukrainian rally - a line of the local cycling community, March 09, 2014.

Photographer: Sergiy Ilchenko.

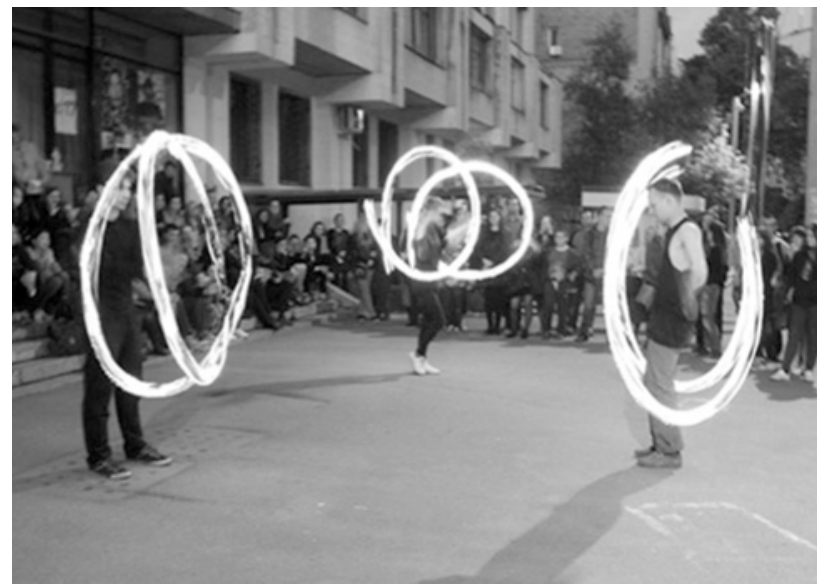

2 .

The fire show on Mystetstv Street during the "Night of Museums", 2017. Photographer: Sergiy Ilchenko. 
The suspension of car traffic, as in the case of regular sporting events or the Kharkiv International Marathon (held since 2014$)^{10}$ or Kharkiv's Cyclist Day (held since 2006), ${ }^{11}$ helps the streets of Downtown reclaim their essential status as a public space (Von Schönfeld/Bertolini 2017). Even the temporary adjournment of car traffic can encourage communication and change spatial function - communication replaces mobility (fig. 1 and 2).

At the beginning of the 2oth century, Anastasia Bozhenko described the events taking place at Chamomile Day, a local Ukrainian holiday:

»Notably, concerning organized charity events, one of them was international Chamomile Day, dedicated to raising awareness and fighting tuberculosis. Furthermore, the urban space, even public transportation was transformed by the festivities, as we can see from the pictures of the event, trams were decorated with wreaths and flowers, which means public transport was also included in the celebration. Buildings were decorated with garlands of white flowers and signs prompting support for the resolution« (Bozhenko 2018: 165).

\section{Inclusion of Urban Spaces}

Collective events that are not connected to a particular place or neighborhood but are held each time in different places, can be attributed to the second type of collective action in public space. Collective action is composed of a myriad of repercussions and unfortunately, dissatisfaction expressed by certain groups can overshadow the understandable feeling that the problem can be solved collectively; so social movements seek a common ground - "positions where social coalitions unite to achieve collective goals (Martin 2003).

In this respect, with the example of Kharkiv's gastro-enthusiast community it can be shown, how they established their claim to use urban space and created the basis for cooperation and communication. This community appeared in Kharkiv in 2013 with the introduction of the first

10 »Kharkiv Marathon has Entered the International Organization Events Calendar«, in: Official Site of Kharkov City Council, Mayor, Executive Committee, January 21, 2014, 09:28, https://www.city.kharkov.ua/uk/news/harkivskiy-marafon-uviyshov-do-kalendarya-zahodiv-mizhnarodnoyi-sportivnoyi-organizatsiyi-22844.html, accessed July 15, 2021.

11 »Bike Day-2019 Took Place in Kharkiv«, in: Official Site of Kharkov City Council, Mayor, Executive Committee, May 19, 2019, 13:24, https://www.city.kharkov.ua/uk/news/-41702. html, accessed July 15, 2021. 
food festival held here, »Day of the Restaurant«. The concept behind the festival is that anyone can open their own restaurant, café, or bar for 24 hours.

The goal of this kind of communal action is to bring people together through the enjoyment of food culture and the social event of eating together. ${ }^{12}$ It is thus a certain rediscovery of the texture of local culture, where urban space is perceived as a platform for bringing together different social groups, and renewing urban enthusiasm, or »renaissance« (Latham 2003). In addition, these collective actions reveal the role of local cultural entrepreneurs, who, as Sharon Zukin says, shift the trend toward the authentic consumption of tangible products and spaces and thereby promote diversity and justice (Zukin 2009).

The new urban culture eventually materializes within these »open spaces $\aleph^{13}$ geared towards active initiatives and creating connections between residents. There is also a revival in the "second line " of urban space - in outdated state grocery stores, once displaced by trading stands. These new open spaces, anti-cafes and small coworking hubs become places of collective action, where urban culture is rediscovered.

Outdated public premises that have lingered for years are now becoming platforms for common development. For example, the urban public association "Critical Thinking ${ }^{14}{ }^{14}$ located on the premises of the club for children and youth »Rassvet« at 6, Maximilianovskaya Street, which used to be a base for $" \mathrm{DASH}{ }^{15}$ (school for young architects) and "Kharkiv Dom Aktera, Lesya Serdyuka ${ }^{16}$ on Manizerom Street 3, which became home to some 30 independent theaters. As well as becoming the venue for the local branch of

12 »Restaurant Day in Kharkiv«, in: Robinzon TV, May 23, 2014, https://www.youtube.com/ watch?v=5tOJIVIIsLk, accessed July 15, 2021.

13 »Small Photo Report from Restaurant Day in Tsyferblat on February 21«, in: Facebook group >Restoranny den v Kharkoves, February 24, 2016, https:/www.facebook.com/ permalink.php?story_fbid $=451018038356393 \&$ id $=344482849009913$, accessed July 15 , 2021.

14 »Public Organization Krytychne myslennja Presents Projects for Architectural Urban Space Development«, in: ART UKRAINE, October 27, 2014, https://artukraine.com.ua/n/ go-kritichne-mislennya-prezentuye-proekti-z-rozvitku-miskogo-arkhitekturnogo-prostoru/\#.YG]raa8zZhE, accessed July 15, 2021.

15 »Design School for Kids and Youngsters«, in: dash! https://dash.vision/\#about, accessed July 15, 2021.

16 »House of Actor after Les Serdyuk«, in: Dom aktera, https://domaktera.kharkiv.ua/ theaters, accessed July 15, 2021. 
the national theater festival »Kurbolesiya« (2010-2017) and the international festival of works in progress »Theatronic « (2011-2017) as well as the puppetry and mixed media festival »ANIMA« (2017) it basically becomes an open space for new theater initiatives.

Coming back to our gastro-enthusiasts' start-up, it is worth taking a look not only at the numerous alliances they created with other associations and urban communities, but assessing what those efforts contributed to the significance of the urban space. Basically, what we are seeing is the community grounding its activities in the rebirth of interest in the city. Here is an example of how the organizers of the food festival »Luk Fest« describe their choice of venue:

»The venue of the new festival is the courtyard of the former estate of the professor of the Kharkov Imperial University, researcher and ornithologist Nikolai Somov. The building was constructed according to the design of A.N. Beketov. Today it is home to the >House of the Doctor-and the Kharkov Medical Society. [...] A large green courtyard stands in the center of the estate, and you will surely be surprised by the rear facade of the building. On September 12, you will discover a slightly different side of our city. $\ll^{17}$

The downtown arena seems to be attracting advocacy from new urban communities, and as the first »Luk« Festival at Kharkiv's Literature Museum demonstrates, ${ }^{18}$ location matters. The long list of various organizations partnering with food festivals displays how colorful and variable these cooperative combinations can be. At different times and at different locations, partner organizations of the gastro-enthusiasts at the »Luk Fest« were: Ziferblat Free Space (later the Lacan intellectual bar), ${ }^{19}$ the combined area of the gallery and cafe »Ampersand food \& art«, anti-cafe »Oblomov«

17 »Today we are Coing to Tell You About the Holding Place of the Second Food Festival LUK, Which Takes Place on September 12 «, in: Facebook group >Lukfest<, August 28, 2015 https://www.facebook.com/lukfestival/photos/a.991177624234508/1022118334473770/, accessed July 15, 2021.

18 Ostapenko, Leonid (2015): »How Was It: Food Festival LUK Took Place at the Literary Museum Garden«, in: VCORODE, June 25, 2015, https://kh.vgorode.ua/news/dosuh_y_ eda/262458-20-kylohrammov-rysa-y-25-kylohrammov-miasnoho-farsha-v-kharkoveproshel-festyval-edy-luk, accessed July 15, 2021.

19 »Intelligent BarLacan«, in: Facebook group ১Lacan<, https://www.facebook.com/lacanbar/, accessed July 15, 2021. 
and »TEPLO / TEPLO «, cafes of the third wave »A7« and »Bourbon«, educational hub and coworking space "Spalah Edu Hub«, musical project »Kultura Zvuka«, ${ }^{20}$ independent city festival »Gesheft Garage Sale« (Odessa), school of young architects »DASH«, the cultural initiative »Fifth Kharkov«, festival »Vertep Fest", the fair of Ukrainian clothing designers »DesignMarket More«, the project »Street Day«, and the festival »Kharkiv Music day ${ }^{21}{ }^{21}$

The unifying feature of these diverse groups is their recognition of the city as a platform for social engagement. This is a neighborhood with a heterogeneous group of residents, since in addition to local residents, there are those who have recently settled in Kharkiv, and visiting students. The majority are not natives to the city center but they are nevertheless part of the urban society. The common ground for this extended community is the creation of a new collective culture (through cooperation/complicity) not based on historical reflections. These new communities actively participate in advocating for the downtown area and its phenomena, its fulfillment and authenticity (in contrast to interpretation of the territory as a resource for appropriation). It seems that such bottom-up efforts are contributing to the domestication of urban spaces. They revitalize the fabric of the city by incorporating all new sites into shared spaces.

\section{Transformation of Space}

A monolith on the outside, the space of consumerism is torn apart by the destructive actions of urban semiotic partisanship. The latter manifest not only as aesthetic qualities, but also as political statements in the public space (Campos 2016). Simultaneously, united by the discovery of the collective, part of the urban community demonstrates a different attitude toward the city. They are attentive toward the location and have a sense of responsibility for the communal (public) space. Regarding the processes that define the reform of urban space, it is this part of the population in collaboration with the art community that becomes the source of »communal tactics « associated with sites of collective endeavor and the creativity of residents, where space is

20 »Music Club /Kultura zvuka«, in: https://kulturazvuka.ua/ua/, accessed July 15, 2021.

21 »Music Day will Take Place in Kharkiv«, in: Official Site of Kharkov City Council, Mayor, Executive Committee, June 20, 2014 10:17, https://www.city.kharkov.ua/ru/news/u-kharkovi-vidznachat-den-muziki--24472.html, accessed July 15, 2021. 
understood as a common resource for future development (Gielen 2015). This is facilitated by the scale of the central quarters built up along the perimeter of 2-5-story buildings and having a complex structure of multi-story buildings of the second line that divide the interior space into chains of small courtyards.

Governmental strategies of establishing order in the form of organized spaces (De Certeau/Mayol 1998[1980]) are limited solely to the facades of main streets and do not encompass courtyards and alleys. Although it seems logical to restore an integral urban fabric, especially since, thanks to collective actions, the city has already been opened up by local residents, and not only in the format of the main streets.

These strategies are largely focused on shaping the media's image of a "successful« Kharkiv and are in line with the liberal rhetoric of capitalism. The argument for this statement is the amount and forms of work carried out in the central part of the city. First, the officials take care of the main streets, or those parts of the city that are always in sight. Second, it's all about the visibility of the results of this work by the municipal authorities. For example, if large mature trees grow on the street, they will be replaced with new decorative ones; the facade of a building (even of an architectural monument) will be painted in a distinct color; the reconstructed sections of the streets will be decorated with diode garlands and facades will be backlit (the simplest way to make taking care of your hometown visible). Third, courtyards will eventually turn into urban voids, since they are not the subject of urban programs.

This is a rhetoric in which:

»media representation and consumer tastes lubricate the wheels of global urbanism, anchoring the power of capital and state in the vastness of our personal desires, convincing us that the consumption of an authentic city is about aesthetics and has nothing to do with power« (Zukin 2009: 551).

The city's shell does not (physically) change the space and is a collection of beautifying techniques that promote a utopian image. On the other hand, the inner space of the neighborhoods constantly transforms due to the incessant usurpation and appropriation of spaces under the cloak of urban micro-operations by the administration and their »dead« (van Assche et al. 2014) planning practices. It is essential to recall that Ukraine belongs to countries with a transition economy in which many of the rules governing construction do not limit the ambitions of developers. So, according to the 
current regulations, for the city center, in almost any place, a building up to 100 meters high with 100 percent development of the site can be erected if it does not contradict the national building codes. Such a rule can hardly be called a limitation.

The downtown arena saturated with graffiti has an annual upgrade in August (during the day of the city) when, with the great efforts of the city maintenance crew it is painted over again fresh. Yet this short-lived measure to restore »order « serves as the canvas for new inscriptions and works of graffiti. This is a daily exercise for establishing presence where:

"public space is understood as an arena of ongoing contestation and negotiation wherein different groups' rights and claims to the city are defined. [...] Each of these concerns - exclusion, encroachment, and claim-making offers a distinct way of attending to contemporary public spaces and the transformations that shape them.«(Koch/Latham 2012: 517).

As illustrated by these activities, the city thrives as a result of a variety of »creative actions " scattered about the common landscape of experience (De Certeau/Mayol 1998[1980]). The way in which we interpret and experience urban character is conveyed by this opinion of Vladislav Krasnoschek (Kharkiv street artist): »I think that an artist who goes out on the street, has to be ready that his [work] will be painted over a minute after he completes it. You can call it an artistic act or performance. One way or another your art will be destroyed. Street art is a fragile endeavor, the walls belong to everyone. ${ }^{22}$ In the ever-changing dynamics of appropriation, transformation, and revision, the aforementioned »creative actions « are characterized by a certain temporality that limits their interference in the urban space.

And this is exactly what happens - not a single new work placed in the city is left without people reacting and can instantly be refuted by other artists or covered up by local residents.26 The compelling aspect of this situation, is that in the city, multiple modes of communication occur on a daily basis and they are simultaneously peppered by destructive episodes in the form of »semiotic partisanship« that violate or interrupt official order (Campos 2016).

22 Kalita, Nastya (2019): »Vladyslav Krasnoshek: About >Completed dissertation and Medical Practice«, in: Yourart, July 17, 2019, https://supportyourart.com/conversations/ krasnochek/, accessed July 15, 2021. 
In some cases, this palimpsestic layering of various interventions culminates in a collective clash (for example, local residents and street artists).$^{23}$

The heterogeneous body of the city also includes public spaces in decline abandoned places (beyond the reach of utility crews and city administration), which, however, play an important role as open zones for meeting and the communal activities of citizens. Paradoxically, here the inactivity of the authorities leads to the initial neglect and decline of these spaces. These are areas near historical and architectural monuments (usually small buildings), which, according to legislation, do not have the potential for expansion and, as a result, do not attract investment capital. All these sites are "dormant", waiting for a chain of micro-processes to begin, in order to be appropriated.

These spots in Downtown Kharkiv can be called »abandoned lands« or "the neglected parts « of the city. Each place like this belongs either to the city or to a private owner. Formally, these places are not urban voids. Moreover, covered with numerous signs of "semiotic partisanship« they resemble ruins, but still remain a living space. The encroaching appropriation of this downtown real estate and restriction of free access to it seems to be refuted only by these interconnected cells of »constant presence«. These spaces, free from excessive regulation, are important for collective action and create a rewarding environment for mutual support. They are the places where local communities (or groups) maintain and manifest their identity. But, as Castells says: „these identities, in most cases, are defensive reactions against the impositions of global disorder and uncontrollable, fast-paced change. They do build havens, but not heavens « (Castells 2011: 68). That is why these spaces can be called »urban lagoons « in a binary opposition to the public spaces created by the authorities.

\section{Discussion}

The communal actions of the residents contribute to the assimilation (domestication) of the urban landscape, but have little to do with its physical transformation. Rather, we speak of assimilation by means of »temporary use« and communal activity (Koch/Latham 2013:9). In the context of prospectively

23 Nikitenko, Ekaterina (2020): »I Will Overpaint You: Why Do Some Graffiti Live No Longer Than One Night«, in: Nakipelo.ua, November 13, 2020, https://nakipelo.ua/ya-tebya-perekroju-pochemu-nekotorye-graffiti-zhivut-ne-dolshe-odnoj-nochi/, accessed July 15 , 2021. 
difficult interactions between formal and informal institutions, in regard to the question of spatial planning (van Assche et al. 2014; Waibel 2016) (especially for countries with transitional economies) issues of developing public (civil) spaces in Ukrainian cities (and Kharkiv in particular) look quite contradictory.

On the one hand, government planning and »order (De Certeau/Mayol 1998[1980]) requires the creation of public spaces. This can be attributed to the desire of cities to become attractive, making them an artifact of appreciation by tourists (Campos 2016: 53). We cannot overlook the fact that public spaces (as a symbol of democratic power) are gradually taking precedence (in the urban landscape) over heroic national monuments aimed at strengthening the collective spirit and other material manifestations of authority (ibid.: 59). The paradox however, is that spaces initially created for public use (inclusive by definition), in countries with transitional economies, are being captured for exclusive use by fractions of civil society (Douglass 2007: 49). Originally intended for eating, walking, and possibly taking selfies (as the »showcases" of modern development) these spaces become cluttered with rules of exclusion, prohibition, and control. At times one may think that the Ukrainian administration is intensely studying academic urban criticism (Jackson 1998; Allen 2006; Zukin 2009) and purposefully reinforcing securitization, pacification, ordering, disciplining, homogenizing, commercializing, and controlling in all facets of public spaces. Respectively, with the loss of inclusive spaces, the efforts of urban planners are rather reduced to the creation of »decorations « for public spaces, and as such, these spaces are deprived of the crucial function of interaction between local residents (Schönfeld/Bertolini 2017).

At the same time, one part of the urban community (united by collective actions and interests) demonstrates attentive care to specific places and shares a sense of responsibility for the communal (public) space. In this case, the researcher is dealing with existent (not developing) spaces understood as places of collective activity and co-creation (Gielen 2015). Thus, the main emblematic faculty of such spaces is the inclusiveness of the latter. It is inclusiveness that transforms these (free) spaces into places of collective action and a rewarding environment of mutual support. These places are situational; they are created through implicit and explicit negotiation, as well as through broadening the array of opportunities and privileges to become places for the exchange of ideas and cooperation (Douglass 2007). 


\section{Concluding Remarks}

Group identity in the local community - and urban culture as a result is not homogenous. On the one hand it involves tendencies of urban space consumption, rather than the tradition of co-activity. At the same time, the fact that certain local residents cooperate and re-adapt the city to modern life, proves the phenomena of a new urban culture. The city is rediscovered through collective endeavors, including: festive processions, urban »occupation", artistic happenings and social engagement. Locally, spontaneous groups emerge, reviving the culture of collective and communal actions. Simultaneously, the public/civic space is perceived as a platform for groups with varying identities to meet. If we accept movement as one of the ways of temporarily assigning space to influencing the perception of the latter, it is possible to define public space as a process. In this case, the question should be asked: "What exactly is the result of the planner's work? - a place or a space? « If space is a process then: "What means does the planner have (not have) to organize it?«

In the context of augmenting the capacity of urban planning, one approach may be to use »domestication « of the adopted plans (as a follow-up process of incorporating political and social projects into the daily practices of citizens) (Koch/Latham 2013). In this case, the traditional approach to planning is preserved and all questions about the relevance of the adopted planning decision are transferred to the implementation (domestication) specialist. Another approach can be based on identifying (when preparing the initial data) and preserving unused areas (»urban lagoons«) for natural social reproduction by the local community when planning urban development, the functions of interaction, and co-creation. 
References

Allen, John (2006): »Ambient Power: Berlin's Potsdamer Platz and the Seductive Logic of Public Spaces «, in: Urban Studies 43/2, 441-455. doi: $10.1080 / 00420980500416982$

Assche, Kristof van/Beunen, Raoul/ Duineveld, Martijn (2014): »Formal/ Informal Dialectics and the Selftransformation of Spatial Planning Systems: An Exploration«, in: Administration \& Society 46/6, 654-683, doi: 10.1177/0095399712469194

Bozhenko, A.O. (2018): Formation of the Urban Way of Life in the Second Half of the XIXth-Beginning of the XXth Century (on the Materials of the City of Kharkiv).

Bresnihan, Patrick/Byrne, Michael (2015): »Escape into the City: Everyday Practices of Commoning and the Production of Urban Space in Dublin«, in: Antipode 47/1, July 2014, 36-54, doi: 10.1111/anti.12105

Campos, Ricardo (2016): »Visibilidades e Invisibilidades Urbanas«, in: Revista de Ciências Sociais: RCS 47/1, 49-76.

Castells, Manuel (2011): The Power of Identity Vol. 14, Hoboken, N]: John Wiley \& Sons.

De Certeau, Michel/Mayol, Pierre (1980): L'invention du quotidien. - English translation: The Practice of Everyday Life: Living and Cooking. transl. by Steven Rendall, Minneapolis: University of Minnesota Press, 1998.

Douglass, Mike (2007): »Civil Society for Itself and in the Public Sphere: Comparative Research on Clobalization, Cities and Civic Space in Pacific Asia«, in: Globalization, the City and Civil Society in Pacific Asia, New York: Routledge, 45-67.

Gielen, Pascal (2015): »Performing the Common City: On the Crossroads of Art, Politics and Public Life«, in: Pascal Gielen/ Sander Bax/Bram leven (eds.), Interrupting the City: Artistic Constitutions of the Public Sphere, Amsterdam: Valiz, 273-297.
Goffman, Erving (2008): Behavior in Public Places, New York: Simon and Schuster.

Harvey, David (2012): Rebel Cities: From the Right to the City to the Urban Revolution, New York: Verso Books.

Jackson, Peter (1998): »Domesticating the Street«, in: Nicholas Fyfe/Jon Bannister (eds.), Images of the Street: Planning, Identity and Control in Public Space, London: Routledge, 176-191.

Koch, Regan/Latham, Alan (2012): »Rethinking Urban Public Space: Accounts From a Junction in West London«, in: Transactions of the Institute of British Ceographers 37/4, 515-529, doi: 10.1111/j.1475-5661.2011.00489.x

Koch, Regan/Latham, Alan (2013): »On the Hard Work of Domesticating a Public Space«, in: Urban Studies 50/1, 6-21, doi: 10.1177/0042098012447001

Latham, Alan (2003): »Urbanity, Lifestyle and Making Sense of the New Urban Cultural Economy: Notes from Auckland, New Zealand«, in: Urban Studies 40/9, 16991724, doi: $10.1080 / 0042098032000106564$

Lefebvre, Henri (1968): Le Droit à la Ville. - English translation: The Right to the City, Writings on Cities, transl. by Eleonore Kofman/Elizabeth Lebas, Oxford: Basil Blackwell, 1996.

Lefebvre, Henri (1974): La Production de l'espace. - English translation: The Production of Space, transl. by Donald Nicholson-Smith, Vol. 142, Oxford: Basil Blackwell, 1991.

Martin, Deborah (2003): »>Placeframing as Place-making: Constituting a Neighborhood for Organizing and Activism«, in: Annals of the Association of American Ceographers 93/3, 730-750, doi: 10.1111/1467-8306.9303011 
Schönfeld, Kim Carlotta von/Bertolini, Luca (2017): »Urban Streets: Epitomes of Planning Challenges and Opportunities at the Interface of Public Space and Mobility«, in: Cities 68, 48-55.

Tarasova, Julia (2012a): »Thousands of Holland fans marched through the center of Kharkov to the Metalist Stadium«, in: STATUS QUO, June o9, 2012, 17:19, https://www.sq.com.ua/ rus/news/videonovosti/09.06.2012/ tysyachi_gollandskih_bolelschikov_ idut_shestviem_po_centru_harkova_k_ stadionu_metallist/, accessed July 15, 2021.

Tarasova, Julia (2012b): „Camping for Holland fans has been officially opened on Zhuravlevka«, in: STATUS QUO, June 08, 2012, 23:15, https://www.sq.com.ua/ rus/news/fotoreportazh/08.06.2012/na_ zhuravlevke_oficialno_otkryli_kemping_ dlya_gollandskih_bolelschikov/, accessed July 15, 2021.

Tarasova, Julia (2012c): »Holland fans with posters >Thank you, Kharkov «are marching again to the Metalist Stadium«, in: STATUS QUO, June 17, 2012, 19:35, https://www.sq.com.ua/rus/news/ videonovosti/17.06.2012/gollandskie_ bolelschiki_s_plakatami_spasibo_harkov_ vnov_idut_shestviem_k_stadionu_ metallist/accessed July 15, 2021.

Vaiou, Dina/Kalandides, Ares (2016): »Practices of Collective Action and Solidarity: Reconfigurations of the Public Space in Crisis-ridden Athens, Greece«, in: Journal of Housing and the Built Environment 31/3, 457-470, doi: $10.1007 /$ slo901-015-9468-z

Waibel, Michael/McFarlin, Colin (2016). Urban Informalities: Reflections on the Formal and Informal, New York: Routledge.
Zukin, Sharon (2009): „Changing Landscapes of Power: Opulence and the Urge for Authenticity«, in: International Journal of Urban and Regional Research 33/2, 543-553, doi: 10.1111/j.1468-2427.2009.00867.x 
